of early maturing breeds and killing off at an earlier stage of fattening than has been customary, the result will be a great economy in concentrated feeding-stuffs, and such a reduction of the head of cattle can be effected as will equalise the demand for feeding-stuffs and the supply. When the total reduction in live stock becomes such that the normal meat supply can no longer be maintained, recourse must be had to increased importation. Should this step prove necessary, it will obviously save tonnage to import meat rather than fodder.

Agriculturists will find many points for criticism in the details of Prof. Wood's estimates, which are admittedly and of necessity only rough approximations in many particulars, but such criticism can scarcely shake the soundness of his general conclusions.

Too much importance cannot be attached to Prof. Wood's appeal for a careful examination of the results of the methods which have been used in Germany for carrying out a policy framed on similar lines, so that we may avoid the mistakes which have been in a great measure the cause of the food troubles of Germany. It is suggested that the essential features of a successful policy must comprise, first, the prohibition of the use of sound potatoes and cereals for any purpose other than human food, with certain limited exceptions; secondly, the setting up of maximum prices, rather than fixed prices, for all agricultural commodities, such prices to be fixed in due relation to one another to ensure maximum production of indispensable products; and lastly, the rigid enforcement of such regulations by the infliction of penalties which none could afford to risk. Prof. Wood is tc be congratulated on the clearest exposition of the food situation that has yet been submitted to the lay public, and the widest possible circulation of his views is eminently to be desired.

C. C.

\section{UNIVERSITY REPRESENTATION IN} PARLIAMENT.

THE provisions of the Franchise Bill as regards the representation of Universities are based on the recommendations of the Speaker's Conference on Electoral Reform, issued early in the present year, under which Oxford and Cambridge retain two members each, London is grouped with Durham, Manchester, Birmingham, Liverpool, Leeds, Sheffield, Bristol, and Wales to form a constituency returning three members, and the Scottish Universities are to form a single constituency returning three members. The degree is to be the basis for electoral qualification. In view of the attacks to which the University franchise has been subject in recent years, this full recognition of the principle of University representation will be gratifying to those who believe that it constitutes a valuable element in our electoral system. As Mr. Balfour said in the House of Commons in July, I9I3, the representation of Universities is an honour paid by the country to the cause of higher education, which gives the power of getting into the House of Commons men of NO. 2505, VOL. IOO] science, men of scholarship, men of special and peculiar gifts quite alien from the ordinary working politician. It is, both in theory and practice, a form of proportional representation, enabling men and women of special training and experience to form themselves into constituencies and to return to Parliament representatives qualified to promote higher education and the advancement of science and learning, aspects of our public life which are least likely to secure representation through the ordinary channels.

The recommendations of the Speaker's Conference, while extending the University franchise to the newer Universities, articulate well with the present system of University representation, save in one particular, viz. the proposal to deprive the University of London of the separate representation which it has enjoyed since r867. NATURE is not concerned with party politics, but there can be no doubt that the reason for this proposal -though no explanation is offered in the report of the Conference-was to form a large University constituency (by grouping London with the newer Universities), which might confidently be expected to return one, or possibly two Liberal members. In the earlier years of its Parliamentary representation London returned three Liberal members -Robert Lowe, Sir John Lubbock, and Sir Michael Foster. At the present time, however, all the University members in Parliament are Conservative or Liberal Unionist, a state of things which is probably responsible for the proposed adjustment. It is most unfortunate, however, that for party reasons the University of London should be victimised by being deprived of its right of separate representation, and this at a time when thousands of its graduates on active service are unable to make their influence felt on the question. If the principle of grouping is sound, it should have been applied to Oxford and Cambridge, which not only retain separate representation, but are also to return two members each.

On the basis of the number of their graduates, neither Oxford nor Cambridge has a stronger claim for two members than London. To secure the representation of the smaller Universities some method of grouping is inevitable; but the result of joining London, with its roll of graduates many times longer than that of any of the other Universities of the group, will be to form an unwieldy and heterogeneous constituency, dominated by the London vote.

The Times Educational Supplement has suggested in a leading article that, "had the history of the University [of London] been less chequered, it may be that it would have retained separate representation." Those who know anything about the University of London will be disposed to think, on the contrary, that the University would be held in higher respect if its history had been more chequered, if it could show more of the scars of battle against ignorance and obscurantism. However that may be, the English system is to build on tradition, and to preserve principles and institutions which, as 
Mr. Balfour has said, have " slowly grown up under the moulding influence of circumstances, acting from generation to generation "; and the surest way of disheartening a University, and " chequering" its future history, is to exacerbate the feelings of its graduates by depriving them of a cherished privilege.

The immediate question is whether some modification of the proposals of the Speaker's Conference is practicable which would not break down the compromise accepted by both political parties. Sir Philip Magnus, Sir William Collins, and Mr. M'Kinnon Wood (all of whom are London graduates), Sir James Yoxall, Mr. Fell, and Mr. George Faber, have put down an amendment to the Bill providing that the University of London shall return one member, and that the other Universities of the proposed group shall form a constituency returning three members. If accepted, this arrangement would mean an increase of one in the total number of University representatives, eleven instead of ten contemplated by the Speaker's Conference. It is expected that the amendment will be moved in the course of a few days. We hope the amendment will be adopted, thus repeating the history of fifty years ago, when a proposal to join London to another University to form a constituency was defeated against the Government, and London obtained the privilege of separate representation which it has since enjoyed.

T. LL. Humberstone.

\section{THE EDUCATION BILL.}

THE history of the measures for reform and improvement in the means and methods of education introduced into the House of Commons since the passing of the Education Act of rgo2, which did so much for advanced education and to increase the public responsibility for all forms of education, has been one long tale of disaster; and Minister after Minister has succumbed to the opposition his measures have provoked.

It would seem, judging by the announcement made by $\mathrm{Mr}$. Bonar Law in the House of Commons on October I9, that the same doleful fate awaits the Bill brought in by $\mathrm{Mr}$. Fisher on August 13 last with such favourable omens. The personality of Mr. Fisher, his known deep interest in the subject, the sound knowledge and experience he has brought to bear upon it, together with the lucid and interesting exposition of the details of his measure, have won for it wide and favourable recognition and a strong body of support, due no doubt to those clauses of the Bill which have for their object the welfare of the child, whether in the condition of infancy or throughout the years of adolescence, so as to secure for the child the fullest opportunity of effective moral, intellectual, and physical training.

The advent and circumstances of the war have awakened amongst all classes of the people, employers and employed alike, a deeper sense of the value of education and of the responsibility of the nation for the adequate preparation of the children for the duties that await them. It has at last been brought home to those engaged in industry and commerce that Germany's position as a formidable rival is wholly due to the splendid facilities she has provided for the due training of her people, and that successful competition with her can be assured only by the adoption of a similar policy. Grave questions of reconstruction are under consideration, but they can be assured of their desired effect only in so far as they appeal to an educated people. The increasing industrial applications of scientific discovery demand a higher range of intelligence amongst all classes, and it is no less important for the well-being of the nation that the ampler leisure now urgently sought should be wisely used and enjoyed-a condition possible only where the means and opportunity of an efficient education exist. The ravages of the war, which has taken so huge a toll of educated young life, furnish another admittedly grave reason why we should at once make provision for the adequate education of all our youth.

Let it be remembered that $\mathrm{Mr}$. Fisher was called from a position of high educational distinction in order that he might bring the ripe fruit of his knowledge and experience to bear upon the problem of ensuring the means of a more efficient education for the people of this country, and that it is little short of a cruel irony to refuse him the necessary time for the full consideration of his proposals. It is true that there are grave objections to some of the administrative clauses of the Bill, especially those which tend to increase the bureaucratic power of the Board of Education, but they are not of the essence of the measure, and may with advantage be taken out of the Bill. As to the threatened opposition of the textile industry, the only answer there can be is that the interests of the child are paramount. It should be possible to arrange upon an agreed measure, so far as the educational clauses are concerned, and so satisfy the ardent desire of the great majority of the people that such a measure should pass into law. There are strong reasons why further time should not be lost, since before the educational proposals embodied in the Bill can have their desired effect there is much to be done in the provision of teachers, equipment, and suitable buildings.

\section{PROF. EDWARD HULL, F.R.S.}

DROF. EDWARD HULL, who died in London on October 18, was born at Antrim, where his father was rector, on May 2r, I829, and had thus reached his eighty-ninth year. Like many of those whose work has lain in the open air, he retained considerable vigour, anc he revisited at the age of eighty some of the scenes of his early observations. His father proposed for him a career in the Church of Ireland, and his early literary and biblical studies no doubt left an impression on his life. Attracted, however, by

NO. 2505 , VOL. IOO] 